\title{
Marketing with Social Media and Strengthening Identity Through Packaging Branding
}

\author{
Putu Gede Surya Cipta Nugraha ${ }^{1 *}$, I Putu Yoga Indrawan² iD \\ 1, 2 Prodi Teknik Informatika, STMIK STIKOM Indonesia, Denpasar \\ *Corresponding author: surya.cipta@stiki-indonesia.ac.id
}

\begin{abstract}
The purpose of this community service activity is to help partners take advantage of social media to expand market share, create business brands or logos as branding in strengthening business identity which will be implemented in product packaging. To achieve the objectives of the activity, the approach method used is interview and observation. The partner in this community service activity is a donut snack entrepreneur which is commonly consumed by children and adults as well as for religious activities. The results of the evaluation with partners on community service activities are that branding and packaging have a big role because partners get donut orders over the phone for religious ceremonies in the local area, where the phone number is obtained from the product packaging. The surrounding community also gave a positive response to social media partners who were used for product marketing. the conclusion of this community service activity went well. Partners are given increased knowledge about business management strategies so that they can continue to exist in the modern era by looking at social conditions, target consumers, current market conditions. Partners are given a business logo design that can be used by partners as a business product branding in the future. The implication obtained by partners is that the business market share is getting wider and builds consumer trust so that business profits increase.
\end{abstract}

Keywords: Digital Marketing, Packaging, Branding

\section{Introduction}

Micro Enterprises are productive businesses owned by individuals and / or individual business entities that meet the criteria of Micro Enterprises as regulated in this Law (Fauzi \& Majalengka, 2020; Prianto et al., 2020). Currently, the number of MSMEs in Indonesia has increased significantly from year to year. According to the Central Bureau of Statistics in 2018, it was found that small and medium enterprises in Indonesia have increased every year besides that BPS also said the number of Micro, Small and Medium Enterprises (MSMEs) reached 64 million (Ardiansyah, 2019). This figure reaches 99.9 percent of all businesses operating in Indonesia, so it cannot be denied that Micro, Small and Medium Enterprises (MSMEs) located in all regions in Indonesia are one of the main drivers of the economy (Ardiansyah, 2019; Prianto et al., 2020).

Kukuh Village is a village located in Kerambitan sub-district, Tabanan Regency, Bali province. In Kukuh Village, there are several MSMEs, one of which is the snacks MSMEs. This snack MSMEs provides types of snacks such as donuts. Donuts are a popular snack or snack in Indonesia. Donut is a type of bread whose cooking process is fried and has a distinctive shape with a hole in the middle like a ring or ball-shaped (Subagjo, 2007). From the results of interviews with the Head of Kukuh Village and MSMEs partners for donut

$\begin{array}{lll}\text { History: } & & \text { Publisher: Undiksha Press } \\ \text { Received } & : \text { 12 December } 2020 & \text { Licensed: This work is licensed under } \\ \text { Revised } & : \text { 08 January } 2021 & \text { a Creative Commons Attribution 3.0 License } \\ \text { Accepted } & : \text { 23 January } 2021 & \text { C) (C) } \\ \text { Published } & : \text { 25 February } 2021 & \end{array}$


snacks, the basic ingredients of donuts are made of wheat flour, sugar, baking powder, salt, eggs, butter and milk as well as the shape is made round. This processed food is very well known in the community, especially in Kukuh Village, both for consumption by children and adults as well as for religious activities. The donut production capacity of partners is quite varied, namely between 70-90 donuts / day. The difference in capacity can be caused by the amount of capital, the availability of raw materials, and the number of workers. Donuts produced by partners are sold at relatively cheap prices, namely Rp. 1000 - Rp. 3000 per fruit. The sales process is carried out by entrusting it to local stalls and local traditional markets.

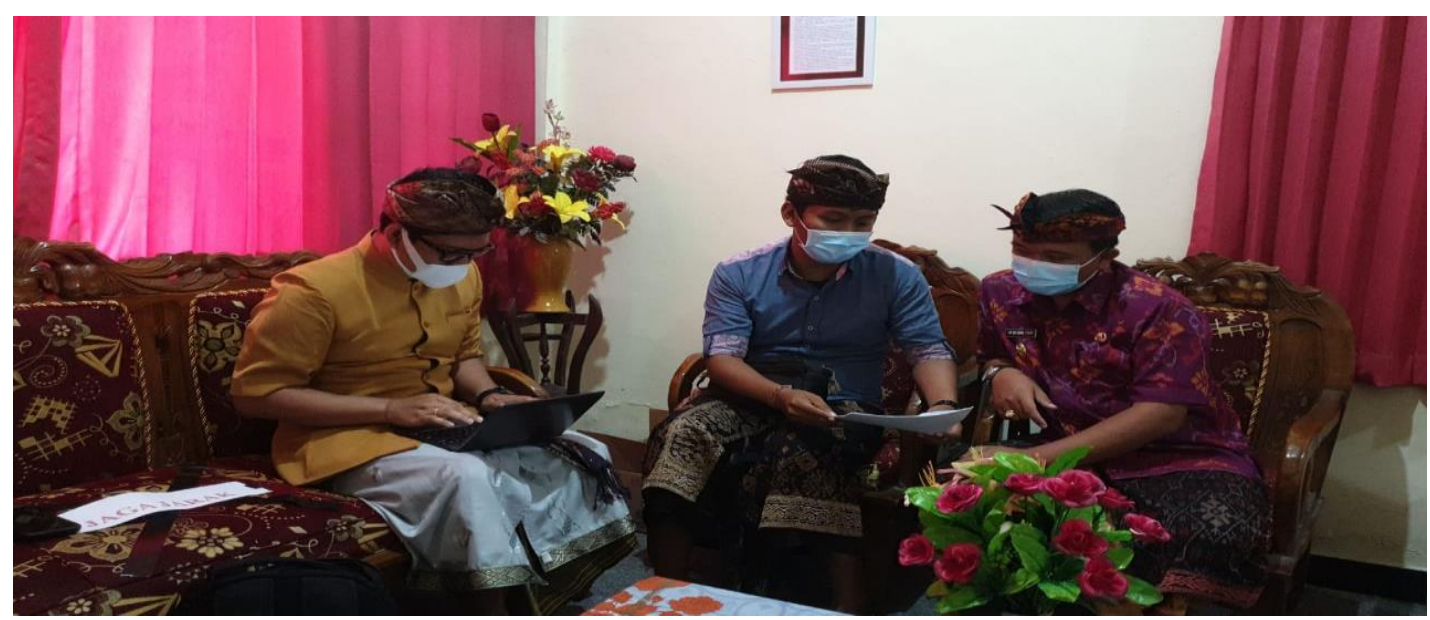

Figure 1. Solid Discussions with Village Heads and Partners

The head of kukuh village also expressed his wish and hope that MSMes in kukuh village, especially donut snack MSMes, have a brand that is characteristic of these MSMes as well as a wider market share, not only in the kukuh village area but can get out of kukuh village. Snack MSMes partners in running their business do not always run smoothly, one of the obstacles felt by this community service partner is a lack of knowledge about product marketing in order to increase selling value and buyer interest. Branding on the packaging is also still simple. The simple thing is that donuts are wrapped in clear plastic without including the logo of the business, which indirectly eliminates the identity of the partners and it is difficult to expand market share, as well as the need to add flavour variants to donuts. Basically, this business is quite promising if it is marketed in various schools, offices or snack shops in other areas.

Research conducted on Product Quality, Packaging, and Brand Image Against Customer Satisfaction states that brand image can be an added value for the product itself, because if the product has a good brand image it can attract consumers to visit or return, buy the product itself (Pesoth, 2015). Brand Image will not significantly affect customer satisfaction, but a good brand image can influence or increase customer buying interest (Fianto et al., 2014; Yuvita, 2019). Besides that, packaging has a significant effect on customer satisfaction (Antari \& Wulandari, 2019). This means that an increase or decrease in packaging will significantly affect the increase or decrease in customer satisfaction. Because good packaging can provide satisfaction to customers separately, this is because the better the packaging of the product, the better the quality that is produced from the product. Other research was also carried out on Marketing Strategies through Social Media Instagram stated that there was an increase in sales using social media Instagram because social media is a powerful way to promote products and services through internet marketing (Untari \& 
Fajariana, 2018). The method is simple but has an extraordinary effect. Based on the analysis of the partners' conditions and the problems faced by the partners, the community service team focuses on helping partners use social media to expand market share, creating a business brand or logo as branding in strengthening business identity which will be implemented in product packaging.

\section{Materials and Methods}

Based on the problems that occur in the conditions of community service activity partners, the stages of the activity plan shown in Figure 2 are carried out.

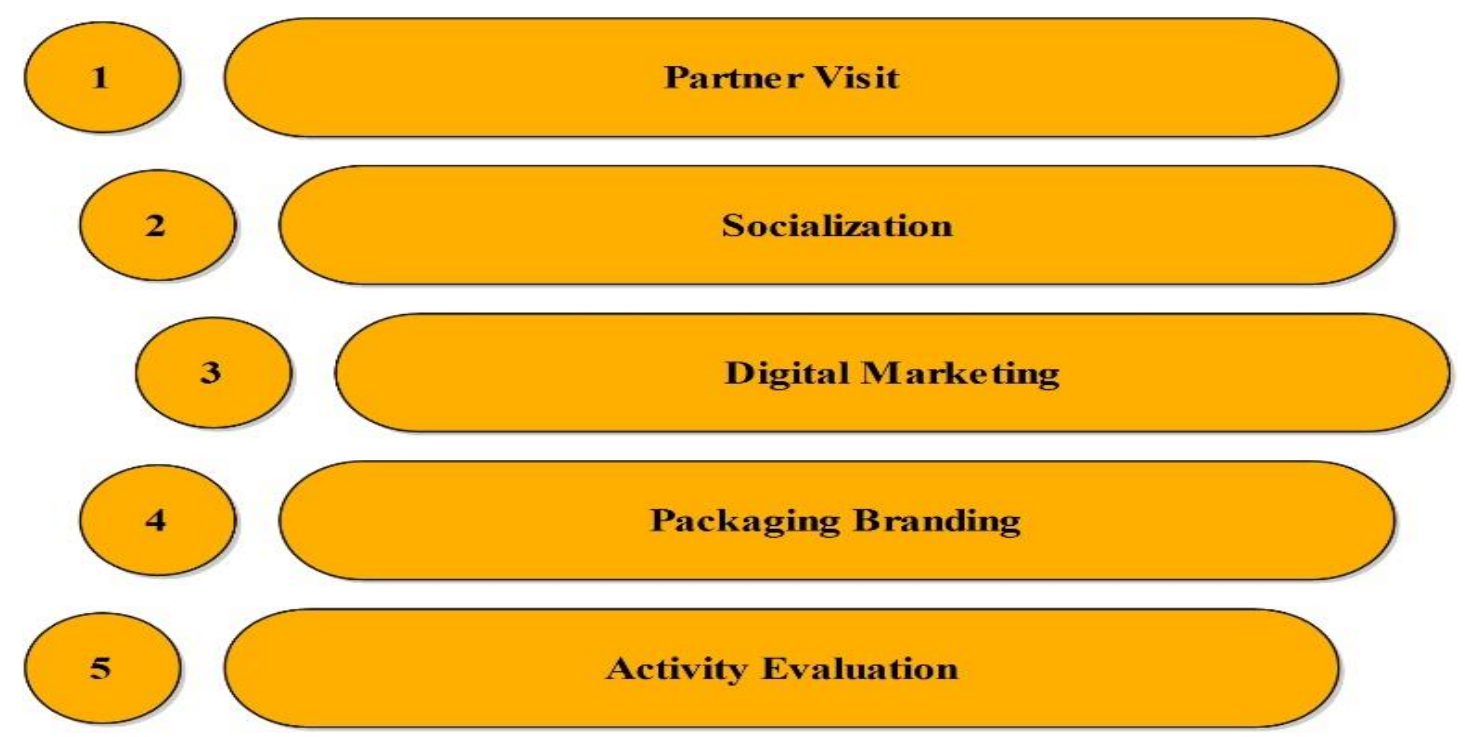

Figure 2. Implementation Method

The first stage of the activity plan is carried out by visiting partners, at this stage holding a focus group discussion (FGD) to find out what problems are happening with the partners. The problem that occurs in partners is the lack of knowledge about product marketing so that it can increase selling value and buyer interest. Branding on the packaging is also still simple. Simple what is meant is that donuts are wrapped in clear plastic without including the business logo, thus indirectly eliminating the identity of partners and it is difficult to expand market share.

After that, the second stage of activities will be carried out, namely the socialization of digital marketing and packaging branding as a solution to the problems found. The output of digital marketing socialization is that partners can make donut businesses with more than one variant and can use social media to increase a wider market share. Meanwhile, the output of the socialization about the urgency of product packaging branding is that partners have increased knowledge and awareness that identity in a business package is an important thing. In addition, design and packaging label stickers will be given according to the character of the partner's request. Furthermore, in the third stage, digital marketing in this case is the practice of socialization that has been provided with how to use social media Instagram to develop market share. Furthermore, in the fourth stage, the package branding plan is given assistance on packaging label design to make it look more attractive and in the end a packaging sticker will be given with a more complete partner identity. Furthermore, in the fifth stage, activity evaluation is carried out to see the results of the community service 
activities given. This evaluation is done by looking at the level of sales figures in one month and analyzing the packaging logo function is functioning properly or not.

\section{Results and Discussion}

Currently, business owners are starting to see the cultural phenomenon of consumption as an opportunity for them to make a profit. Actually, consumptive behavior has two useful sides, namely positive and negative. For traditional people, consumptive behavior is considered a cultural tragedy that must be minimized. Meanwhile, for entrepreneurs and modern society it is considered a positive habit so as not to be left behind by the times (Antari \& Wulandari, 2019; Were et al., 2019). This is one of the reasons for entrepreneurs to continue to exist in the modern world. This is what one of the partners wants in STMIK STIKOM Indonesia lecturer community service activities.

Mrs Sukarini is one of the partners in the implementation of community service on strengthening identity through product diversification and packaging branding at her Donut Snack business. This identity strengthening is given so that partner businesses continue to exist in the modern world. In this activity, the first thing that is done is a visit and a small discussion to get the problems felt by the partners. On this visit the chief executive conveyed the objective of holding community service and gave directions on how the activity flowed. After conducting discussions, the chief executive and partners found an agreement to hold the next activity in the form of socialization of social use product diversification and packaging branding according to the problems experienced by partners. The socialization was held on November 12, 2020, Thursday in the Kukuh Village office hall. The topic of socialization starts from what is digital marketing and the importance of digital marketing to build a marketing strategy and what is packaging branding.

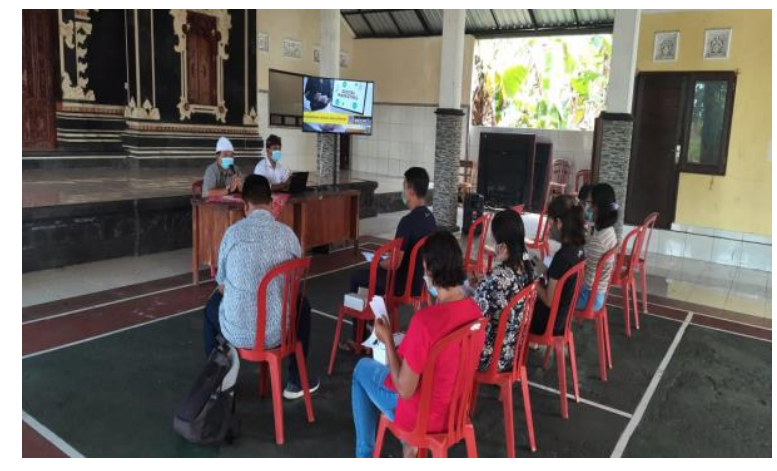

Figure 3. Dissemination of Digital

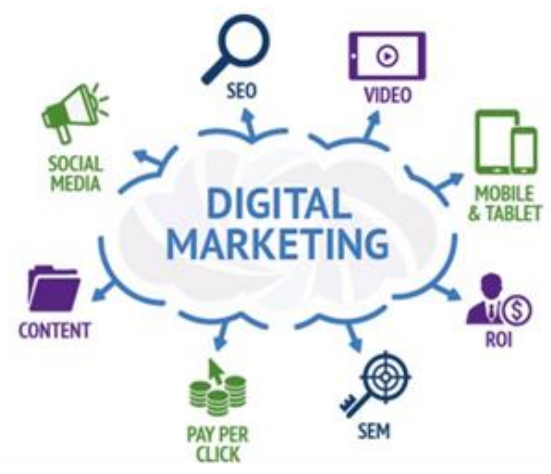

Figure 4. Digital Marketing Materials

Marketing and Branding with Partners

The material presented for the first time by the community service implementation team was about digital marketing. Previously, partners did not know about a marketing strategy and increasing sales through digital marketing. The chief executive tries to explain in an easy and understandable manner so that partners understand the meaning of digital marketing. In this case, digital marketing generally leads to the practice of marketing products from various fields using social media. When communicating with partners, namely Mrs. Sukarini, the chief executive gave a question to the partners about what types of social media the partners knew and what social media partners used the most.

With regard to market opportunities, current target users or consumers tend to like something new seeing the social conditions of the times. Consumers usually see Instagram as a way to get prices, information, photos related to new things, especially the culinary world. 
Instagram is the most competitive social media widely used, namely equal to $74.1 \%$. Potential to generate sales getting higher by exploiting various types of digital media has characteristics and advantages on its features. So that it can it is said that it is getting higher the use of digital media is getting high level of sales (Ayuni et al., 2019). Basically, the purpose of providing socialization about digital marketing is that the use of social media as a marketing tool offers attractive advantages. Among them are helping business users improve their image by managing good relationships with customers, thereby increasing sales and reducing costs for retaining customers. Another advantage, sellers can easily interact with customers via social media and can build trust to share services with customers. Having a good relationship with customers is very helpful for the seller in many ways so that it can provide profit for the business (Alfajri et al., 2019). The next activity is about providing packaging branding to build identity, build community trust and increase the selling power of donut snacks. The purpose of this branding is one of the most beneficial things for business actors. Strong branding will make customers trust a product more and foster a sense of loyalty in a product.

The design that can be an option for partners can be seen in Figure 6. The plastic mica box that will be used for packaging donut snacks measuring $8 \times 8 \mathrm{~cm}$. In the previous packaging, the partner only used ordinary plastic and did not include the business identity.

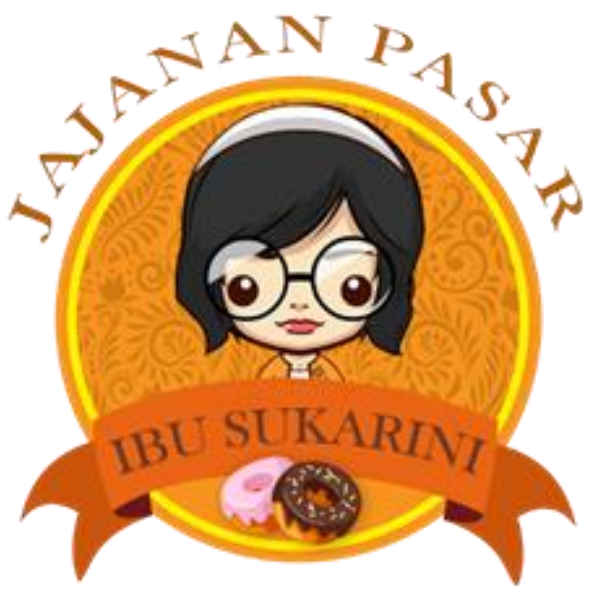

Figure 5. Product logo

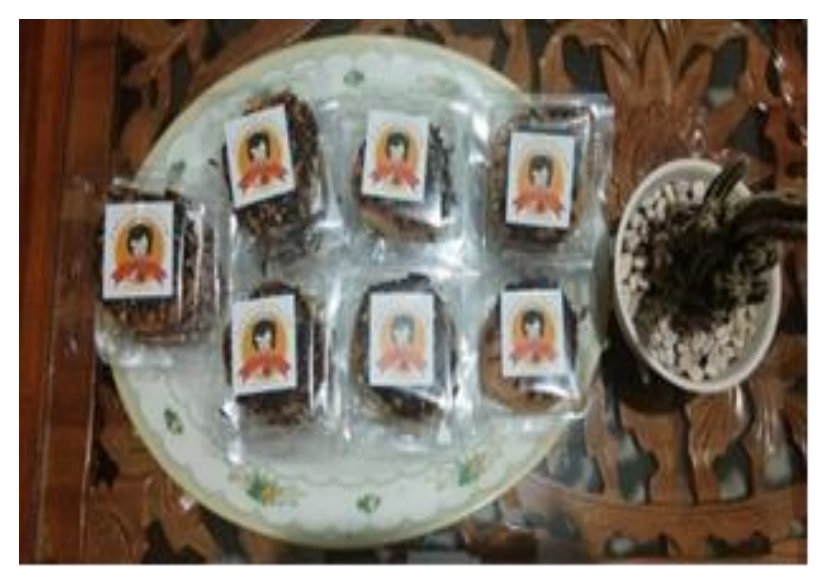

Figure 6. Donut Packaging With a Flavor Variant

This community service activity also requires an evaluation in providing outreach and assistance. Evaluation of activities is carried out by looking at the level of numbers from the results of partners' knowledge skills before and after the socialization and seeing sales figures in one month and analyzing the function of the packaging logo to function properly or not.

On the graph shown in the figure 7 shows the level of ability of socialization participants before and after socialization about social media, branding and packaging. Prior to the socialization, the participant's ability level was $50 \%$, while after the socialization the participant's ability increased to $93 \%$. This shows that the socialization activities have been carried out well and the ability of socialization participants has increased. Branding and packaging have a big role because Mrs. Sukarini got her donut order by telephone for religious ceremonies in the local area, where the telephone number was obtained from the product packaging. 


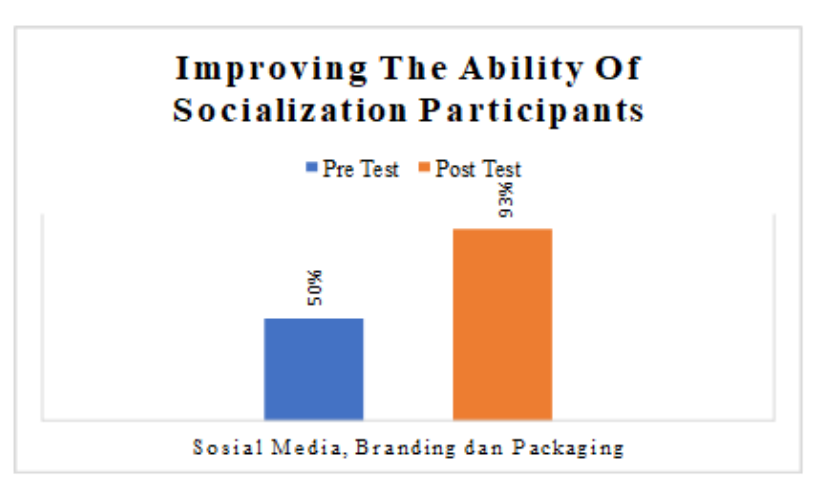

Figure 7. Improving The Ability Of Socialization Participants

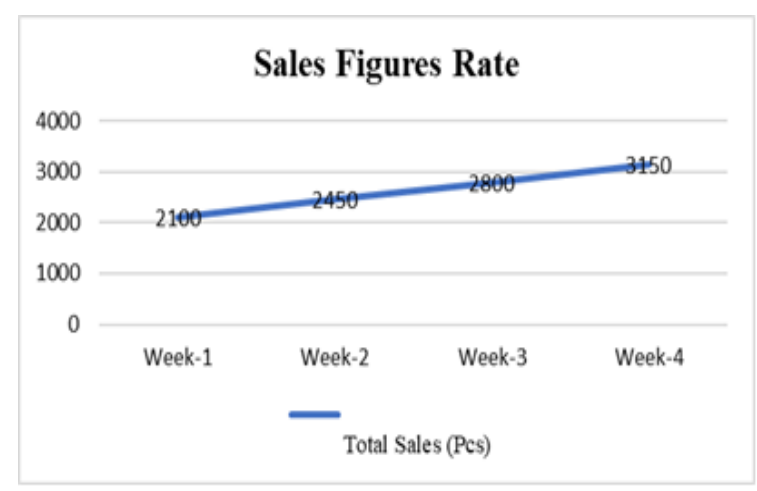

Figure 8. Sales Figures Rate

The graph shown in the figure 8 shows the level of sales figures over a period of 1 month. From this graph, it can be explained that the level of sales every week has increased, this is because currently partners already have their own branding and packaging as a business identity. The surrounding community also gave a positive response to social media partners who were used for marketing. Partners also expressed their gratitude because there had been an increase in sales which indirectly provided profit to the business. In addition, partners are very happy to get additional knowledge about social media, branding and packaging that can provide a positive aura towards the progress of their business. Activities run well, smoothly and are felt to provide benefits to partners in addition to knowledge but also in the form of building identity, building consumer trust and increasing the selling power of donut snacks.

\section{Conclusion}

Based on descriptions and explanations of the socialization and assistance of donut snack business partners on social media, branding and packaging, a conclusion can be drawn that this community service activity is going well. Partners are given increased knowledge about business management strategies so that they can continue to exist in the modern era by looking at social conditions, target consumers, current market conditions. After being given knowledge about the role of social media, branding and packaging in developing a donut snack business, a business logo design is also given that can be used by partners as branding for future business products. All things given are aimed at expanding market share and building consumer trust so that later operating profits will increase. Suggestions that can be given are the sustainability of activities. Not only social media, branding and packaging, but also from partners expecting a marketing strategy such as e-commerce user training that can provide benefits to facilitate communication between producers and consumers, expand the reach of potential consumers with a wide market, and simplify the sales and purchase process.

\section{Acknowledgement}

The author would like to thank STMIK STIKOM Indonesia which has provided financial support for this Community Service Activity.

\section{References}

Alfajri, M. F., Adhiazni, V., \& Aini, Q. (2019). Pemanfaatan Social Media Analytics Pada Instagram Dalam Peningkatan. Interaksi: Jurnal Ilmu Komunikasi, 8(1), 34. https://doi.org/10.14710/interaksi.8.1.34-42. 
Antari, N. N. W., \& Wulandari, R. (2019). Penguatan Identitas Melalui Branding Kemasan dan Diversifikasi Produk Usaha Comel. Studi Kasus Inovasi Ekonomi, 3(01), 5-12. https://doi.org/10.22219/skie.v3i01.7805.

Ardiansyah, T. (2019). Model Financial Dan Teknologi (Fintech) Membantu Permasalahan Modal Wirausaha UMKM Di Indonesia. Majalah Ilmiah Bijak, 16(2), 158-166. https://doi.org/10.31334/bijak.v16i2.518.

Ayuni, Q., Cangara, H., \& Arianto, A. (2019). The Influence of Digital Media Use on Sales Level of Culinary Package Product Among Female Entrepreneur. Jurnal Penelitian Komunikasi Dan Opini Publik, 23(2). https://doi.org/10.33299/jpkop.23.2.2382.

Fauzi, H., \& Majalengka, U. (2020). Pelatihan Manajemen Keuangan Bagi Pelaku UMKM. BERNAS: Jurnal Pengabdian Kepada Masyarakat, 1(3), 247-255. https://doi.org/10.31949/jb.v1i3.324.

Fianto, A. Y., Hadiwidjojo, D., \& Aisjah, S. (2014). The Influence of Brand Image on Purchase Behaviour Through Brand Trust. Journal of Business Management and Strategy, 5(2), 58-66. http://www.academia.edu/download/50315848/6003-22562-1PB.pdf.

Pesoth, M. C. (2015). Pengaruh Kualitas Produk, Packaging, Dan Brand Image Terhadap Kepuasaan Pelanggan Pada Perusahaan Rokok Dunhill Di Kota Manado. Jurnal EMBA, 3(3), 1101-1112.

Prianto, A., Kurniati, I., Wahyudi, M. T., \& Yulistia, E. (2020). Berbagai Faktor Penentu Kesiapan Untuk Berubah Dan Pengaruhnya Terhadap Keberlangsungan Kegiatan UMKM Di Wilayah Terdamak Wabah Covid-19. Capital: Jurnal Ekonomi Dan Manajemen, 4(1), 14. https://doi.org/10.25273/capital.v4i1.7356.

Untari, D., \& Fajariana, D. E. (2018). Strategi Pemasaran Melalui Media Sosial Instagram (Studi Deskriptif Pada Akun @Subur_Batik). Widya Cipta - Jurnal Sekretari Dan Manajemen, 2(2), 271-278.

Were, S., Miricho, M., \& Maranga, V. (2019). Customer-Employee Encounter: A Review of Customer Quality Control on Restaurant Food Service. International Journal of Management, Innovation \& Entrepreneurial Research, 5(2), 1-10.

Yuvita, H. (2019). Pengaruh Brand Image Dan Sales Promotion Terhadap Keputusan Pembelian Melalui Brand Equity (Survei Terhadap Nasabah Bank Bni Syariah Di Kota Palembang). MIX: Jurnal Ilmiah Manajemen, 9(1), 431-440. https://doi.org/10.22441/mix.2019.v9i3.004. 